\section{New Directions for Economics}

\section{GREGORY C. DAHL}

\section{Abstract}

Recent developments in both the Bahá'í community and the field of economics have opened up new vistas in the application of Bahá'í principles to economic questions, both in theory and in practice. The Bahá'í community has grown enough that the Universal House of Justice, in its 1 March 2017 message, has called on Bahá'ís to concern themselves increasingly with the inequalities in the world and to bring their personal lives and the actions of their Bahá'í communities more in line with the high moral standards and principles of compassion and service in the teachings of their Faith. At the same time, the economics profession is more open to new directions of thought and research following the financial crisis of 2007-08 and the subsequent global recession, which exposed the shortcomings of the macroeconomic models that the profession had spent the previous several decades constructing. Some of the fields that appear most fertile for the application of Bahá'i principles to current economic problems are reviewed in this article.

\section{Résumé}

Des développements récents, tant dans la communauté bahá'íe que dans le domaine de l'économie, ont ouvert de nouvelles perspectives pour l'application théorique et pratique des principes bahá'ís aux questions d'ordre économique. La communauté mondiale bahá'ie ayant atteint un niveau de croissance suffisant, la Maison universelle de justice a, dans un message qu'elle leur a adressé le 1er mars 2017, exhorté les croyants à se préoccuper de plus en plus des inégalités dans le monde et à veiller à ce que leur vie personnelle et les actions de leurs communautés bahá'ies soient de plus en plus au diapason des normes morales élevées et des principes de compassion et de service enchâssés dans les enseignements de leur foi. En même temps, depuis la crise financière de 20072008 et la récession mondiale subséquente, qui ont révélé les lacunes des modèles macroéconomiques que la profession avait construits au cours des décennies précédentes, la profession d'économiste s'ouvre davantage à de nouveaux courants de pensée et de recherche. L'auteur examine ici certains des champs les plus fertiles pour l'application de principes bahá'ís aux problèmes économiques actuels.

\section{Resumen}

Los desarrollos recientes tanto en la comunidad baháí como en el campo de la economía han abierto nuevas perspectivas en la aplicación de los principios bahá'ís a las preguntas económicas, tanto en la teoría como en la práctica. La comunidad bahá'í ha crecido lo suficiente para que la Casa Universal de Justicia, en su mensaje del 1 de marzo de 2017, pidió a los bahá'ís que se preocupen cada vez más de las desigualdades en el mundo y traigan sus vidas personales y las acciones de sus comunidades bahá'ís más en línea con los altos estándares morales y los principios de compasión y servicio en las enseñanzas de su Fe. Al mismo tiempo, la profesión de la económia está más abierta a nuevas direcciones de pensamiento e investigación después de la crisis financiera de 2007-08 y la posterior recesión global, que expuso 
las deficiencias de los modelos macroeconómicos en la cual la profesión duro décadas construyendo. Algunos de las areas que parecen más fértiles para la aplicación de los principios bahá'ís a los problemas económicos actuales se revisan en este artículo

\section{BACKGROUND}

Since I first attempted a survey of the Baháí teachings on economics more than 40 years ago ("Economics and the Bahá'í Teachings") and some of the areas within economics where the Bahá'í teachings could be fruitfully applied (“Evolving Toward a Bahá'í Economic System”), there have, of course, been many changes in the Bahá'í community as well as in the field of economics. The Bahá'í community has grown substantially both in numbers and in visibility. In those earlier years of the Faith, Bahá'ís necessarily had to concentrate primarily on building their Bahá'í communities rather than concerning themselves with the problems of society around them. Working to bring the teachings of their Faith to mankind held out the hope and expectation of addressing the causes of the problems afflicting the human race, while, owing to their small numbers, any endeavors in direct social action would have had only minimal effect. Despite a few notable efforts-for instance, in the establishment of schools and in medical services-progress with social and economic development initiatives was limited. In more recent years, however, the Universal House of Justice has been gradually calling on Bahá'ís to engage in the discourses of society and has encouraged them, as a natural result of their growth as local communities, to address social issues (Ridván 2008; Riḍán 2010). Indeed, a major theme of the junior youth spiritual empowerment program pursued by Bahá'ís around the world is to sensitize youth ages 12 to 15 to the needs of their local communities and to encourage them to take initiatives aimed at improving the societies in which they live.

Recently, the Universal House of Justice has addressed a significant message to the Bahá'ís of the World dated 1 March 2017 regarding the "extremes of wealth and poverty in the world [that] are becoming ever more untenable.” They call on Bahá'ís to identify ever more strongly with the plight of their fellow human beings, as " $[t]$ he welfare of any segment of humanity is inextricably bound up with the welfare of the whole," and to increasingly "make their own individual and collective contributions to economic justice and social progress wherever they reside." This call builds upon a view enunciated in their earlier messages, notably the Ridván 2010 message, that social change should involve everyone in society in a cooperative endeavor and can often be initiated at the level of the local community. Theirs is not just a simple call to charity but rather to "addressing the root causes" of poverty, a far more profound challenge.

How are Bahá'ís to meet this challenge? There is no specific economic 
system prescribed in the Bahá'í Writings, but many of the teachingssome of which are discussed belowbear directly on economic issues. It would not be realistic to expect, however, that the mere exposition of ideas will result in significant reform of economic systems. Humanity has become too cynical and too distracted by petty conflicts and the clamor of opinions to pay much attention to idealistic pronouncements. And any effort at systemic reform, even with a well-conceived plan of action, requires an enormous social impetus to overcome existing power structures and vested interests.

The Universal House of Justice has been calling Bahá'ís to an entirely different approach to social progress, one involving community building at the local level. They are now asking that this process of learning about community building be expanded to include considerations of economic justice. Bahá'ís are at an early stage of engaging with such broad social issues, but they may well find that there are many opportunities for individuals and local communities to begin addressing the causes of inequities at a practical level, starting not with economic or political theories but with their own actions based on their observations of those causes and motivated by their desire to serve their communities. As a result of experience gained in this way, new methods of tackling social problems may emerge. These methods may involve intangible factors such as social attitudes and prejudices, rather than material factors such as the lack of income or wealth, and may spring from the grass roots rather than emerging top-down through government programs.

Indeed, Bahá'ís view all aspects of life as one interrelated whole, whether considered from the perspective of the individual or the society, the spiritual or the material, the local or the global. ${ }^{1}$ Economics is only one aspect of, or perspective on, this whole, inseparable from the rest, and solutions to "economic" problems may well be found in what we normally view as other aspects of life, such as religion, ethics, morality, and community building. Needless to say, this approach is quite different from the usual practice in the academic field of economics.

In his keynote address to the 2016 annual conference of the Association for Baháí Studies, former member of the Universal House of Justice Dr. Farzam Arbab suggested that Baháís in every field of endeavor should examine the work of their discipline and begin a process of identifying which aspects might be seen as useful in the context of the Bahá'í teachings and which might not (15). Given

1 For example, the Universal House of Justice warns against thinking in terms of "false dichotomies" and quotes a letter written on behalf of Shoghi Effendi in which he states "[ $[\mathrm{w}]$ e must take the teachings as a great, balanced whole" (Message to the Conference of the Continental Boards of Counsellors dated 28 December 2010). 
that social and political structures in the world appear to be crumbling, it would not be surprising if a large part of the intellectual underpinnings of the present (dis)order, including the field of economics, might need to be rethought, or even replaced.

While the Bahá'í community has been gradually increasing its involvement with economic issues, there has simultaneously been turmoil within the field of economics. When I began my doctoral studies in economics at Harvard in 1969, computers were new and the ability to analyze data and draw conclusions about relationships between different variables was exciting. I was coming from an undergraduate major in electrical engineering, and although I was not the most outstanding student as an undergraduate, the Economics Department evidently was looking for students with my background. Macroeconomics was beginning what would prove to be several decades of development of econometric models attempting to measure and then predict the relationships between influences on the economy and how the economy would respond to those influences. The modeling, and thinking, was of an engineering mindset: in terms of mechanistic systems or "black boxes" whose internals were unknown but which had inputs, such as "policy levers," and outputs, such as employment levels and prices, that could be observed and predicted, much like the electrical circuits I had been studying.

Coming from my engineering background, this approach struck me at the time as misguided, and nothing that I have encountered since has changed that view. Human societies are not like machines. They are highly complex and unpredictable, and they evolve, sometimes with sudden changes. ${ }^{2}$ In electrical engineering, one works with actual black boxes (integrated circuits are almost always encased in black plastic boxes), but the way circuits behave is well understood and quite precise, so the relationship between inputs and outputs is highly stable and predictable. ${ }^{3}$ Economic systems,

2 Economist Paul Ormerod emphasizes this viewpoint in his 1994 book, The Death of Economics, in which he writes: "We need to abandon the economist's notion of the economy as a machine, with its attendant concept of equilibrium. A more helpful way of thinking about the economy is to imagine it as a living organism" (151). He also points out that, like natural systems, economies are subject to unpredictable external shocks and sudden changes (211).

3 Tellingly, in contrast to engineering, with its calculations that include known margins of error, e.g., $232+/-5$, there is no effort in the mathematics of economics to explicitly take into account the often very large margins of error of the data that are used as inputs. Economic data usually derive from heterogeneous sources and are subject to wide variations in quality and accuracy. Anyone working with economic statistics understands the uncertainties involved, but that understanding is often not preserved as the data are reported on by the press or used in models or as the basis of policy decisions. 
however, are not natural phenomena. They are created by human beings as part of our social systems. In this sense, economics could be considered as overlapping with law, as many of the parameters of modern economic systems are prescribed in laws and regulations and administered by institutions that have legal charters. Just as people often fail to obey other laws and regulations, they often fail to obey economic "laws," such as those governing rational behavior. When economics is viewed in this way, it is clear that economies are not smoothly functioning machines; rather, they reflect the characteristics of humans, including emotions, irrationality, herd behavior, and the need to understand complex realities through simplifications.

In fact, the economic system, including modern money, doesn't exist at all except as social contracts and mental constructs. As member of the Universal House of Justice Paul Lample has noted, "most of what we perceive to be reality-the world with which we interact every day-is not physical reality at all. It is social reality” (7). 'Abdu'l-Bahá remarked that "[t] he reality of man is his thought" (Paris Talks 9). Indeed, almost all the problems and issues that humanity is facing in today's world are created by humans and are thus part of "social reality." This reality, having been created by humans, is not immutable and can be changed or even completely remade by them. So, the most important questions about economic systems are not about their internal parameters but about how they change and can be improved.

Another problem I saw with economics as a discipline was that it was becoming far too isolated and concerned only with its own models. Macroeconomists tended to see the sometimes abrupt and unforeseen shocks to economic systems as simply "exogenous," that is, outside the scope of their analysis and models, preferring to focus on the beautiful equilibria predicted by their models. Essentially, their view was that economics is a separate discipline from political science, psychology, medicine, anthropology, or any other discipline, and economists could not be expected to take all these other factors into account. This rather isolationist attitude was a major departure from the earliest practice of macroeconomics, which was often called "political economy" and which took a much more holistic view of human society. ${ }^{4}$

4 Adam Smith, who is primarily remembered today for the assertion that self-interested behavior would lead to economic prosperity through the "invisible hand" of the market, was also famous in his time as a philosopher and for his book The Theory of Moral Sentiments (Ormerod 212). Nava Ashraf has written about the parallels between his views and the findings of both modern psychology and behavioral economics, pointing out that, in Moral Sentiments, “Adam Smith's world is not inhabited by dispassionate rational purely self-interested agents, but rather by multidimensional and realistic human 
My reactions to the field were also informed by my Bahá'í upbringing. As a Bahá'í, I saw the human experience as a highly integrated whole, with spiritual dimensions as well as material ones. Thus, like other people professing religious values, I saw analysis of economies as normative and not just positive. For me, the interesting questions were what an economic system should look like, not so much what the present systems looked like, although understanding the latter would naturally be a prerequisite and basis for conceptualizing possible futures and how such futures could be achieved in practice. And any consideration of economic problems would need to include questions such as whether material consumption is really the main source of human happiness and how moral and spiritual values should be reflected in economic systems, going far beyond simple questions of the level of economic output and its distribution.

Given these various misgivings about the field of economics, I was very happy to be able to pursue a career as an economist at the International Monetary Fund (IMF), engaged in real-world policy issues facing countries-issues usually more political than economic in nature, involving simple accounting relationships rather than complex economic relationships. In this way, I was able to avoid what I felt was a relatively fruitless

beings" (Ashraf, Camerer, and Loewenstein 142). digression in the work of most academic macroeconomists.

While the mainstream of macroeconomics was moving in a different direction, a few isolated voices maintained a social consciousness perspective within the field over these decades, emphasizing the inequalities and injustices that are inherent in the capitalist system. For example, Stephen Marglin has been teaching an alternative (or "heterodox") economics course for undergraduates at Harvard for some years and has written a book titled The Dismal Science that emphasizes the importance of community, a direct challenge to mainstream economics. ${ }^{5,6}$ The principal shortcoming of such critiques of capitalism, however, has been the lack of convincing alternatives, given that the socialist experiments of the twentieth century collapsed spectacularly from serious inefficiency and corruption and that capitalist systems have already incorporated many socialist elements of social protection and welfare. Tearing down one intellectual structure is not the same as building a new one.

During this time, more and more economists also began examining the

5 See also his talk "Heterodox Economics".

6 I am personally indebted to Professor Marglin for his required microeconomics course, one of the first I took as a graduate student at Harvard, which helped protect me from the 40-year detour into mathematical abstractions upon which the field of economics was embarking at that time. 
weaknesses in the "orthodox" or "neoclassical" economic theories and made efforts to modify or extend those theories-for example, by introducing the possibility of multiple equilibria in their models. Younger economists tended to move into microeconomic fields of inquiry such as health, education, and behavioral economics, where the restrictive assumptions of the neoclassical view of economic man as a utility-maximizing machine didn't apply and greater integration with other disciplines was possible. Perhaps as a result of the obvious weaknesses in the neoclassical framework for addressing current economic problems, the field of economics has also been moving away from pure theory, or theory with simulations, and toward more empirical work (Hamermesh 168). Economists have taken the analytic tools of their profession and applied them to a wide variety of interesting but narrower questions, as popularized in the 2005 book Freakonomics by Steven Levitt and Stephen Dubner. However, the result has been that less attention is being paid to the big structural and policy questions of macroeconomics that used to be the main focus of the field, such as economic justice, employment, growth, trade, global integration, economic and financial stability, and curbing abuses of the free market economy such as monopoly power and pollution.

Then, in 2007-08, events gave a big impetus to these trends. The global financial crisis, with its collapse of important financial institutions and credit and the concomitant contraction in economic activity, revealed for all to see that many of the assumptions underlying macroeconomic models were unrealistic and that reliance on these models and similar methods of financial analysis based on historical data, such as value at risk (the statistical method by which banks would assess the riskiness of their assets), had failed to anticipate or prevent an enormously costly economic downturn. Illustrating the hit to the reputation of the economics profession generally, Queen Elizabeth, after hearing a briefing on the financial crisis in November 2008, famously asked, "Why did no one see it coming?” (Giles).

This obvious failure has prompted a certain amount of soul searching among leading economists and policymakers. In March 2013, at a London School of Economics seminar in honor of Mervyn King, the retiring Bank of England governor, Olivier Blanchard, economic counselor of the IMF, said, "Humility is in order," and Professor Lawrence Summers of Harvard University, former Treasury secretary of the United States and former president of Harvard, said, "This crisis will force a substantial reconstruction of macroeconomics" (London School of Economics). It had become apparent that the macroeconomic models economists had spent most of their time formulating had been calibrated with data covering a period of relative financial stability, that financial crises were actually much more frequent and severe than assumed (Taleb), and that 
most models failed to incorporate the financial sector at all, although problems arising from finance turned out to be a much more important cause of economic shocks and decline than the loss of output due to imperfect fine-tuning of economic cycles (Broadberry and Wallis). While econometric models are now still being used, they are being treated with more caution in policy circles. Of course, it is still useful to study macroeconomic relationships in terms of cause and effect, such as what the likely impact on an economy would be from raising interest rates or adjusting tax laws. People respond to incentives as well as laws, and this is the essence of public policy. But it is now increasingly recognized that these relationships are not as stable and predictable as previously thought, that there can be huge gaps between economic models-both calculated models and those mental frameworks by which we make sense of the world-and real-world outcomes. For example, a current issue of considerable importance is that the models used by Western central banks to guide their policy decisions-regarding the links between monetary policy and the response of prices and economic activity - are not yielding the expected results, calling into question the entire framework of monetary policy (Yellen). The realization that the existing models may not be correct presents a fundamental challenge to the accepted concepts in the field of macroeconomics, and while the field has already started to move in new directions, a space has opened up for more innovative approaches.

Perhaps the solution to these problems in the economics profession lies in the recognition that economic systems cannot be fruitfully studied as isolated from other aspects of human society (Etzioni). The barriers between economics and other fields of study, and between economists and the general public, need to be further demolished. There seems to be a natural tendency for specialists in every field to develop their own vocabulary, perhaps as an insecurity-fueled defense mechanism, to keep others from seeing clearly the weaknesses of the discipline (as when doctors refer to "nosocomial infections," diseases that are contracted primarily in hospitals). Certainly, economics has its share of such specialized language. Although it is hard to know whether this phenomenon is greater in economics than in other fields, perhaps the resentment of outsiders to the sense of superiority many economists exhibit may be due to the fact that everyone is directly affected by economic policies and therefore naturally wishes to understand better the forces that are affecting them. This effect would be much less noticeable in, say, archeology or astronomy, but it is clearly visible in fields such as medicine that are similar to economics in their relevance to daily life.

While the field of economics has been facing internal challenges, on a larger stage recent turmoil in national politics in a number of important 
countries, resulting from growing dissatisfaction with the status quo on the part of large segments of the population, is also providing an impetus to question current economic and political systems and to consider far-reaching reforms. As the respected chief economics commentator of the Financial Times, Martin Wolf, wrote recently, "It is time for re-thinking along many dimensions" (11).

Against this background of a general questioning of existing social structures, and of the need to break down the barriers between economics and other disciplines and to work toward an inclusive process of the generation, dissemination, and application of knowledge, this article is addressed to anyone interested in the issues discussed, not just to professional economists. What I will attempt below is a brief and somewhat superficial review of a few of the numerous areas in the fields of economics and public policy that are the subject of current debate-areas where fresh work and innovation benefitting from a Bahá'í perspective could make a positive contribution. The focus is on topics with a potential for immediate applicability or experimentation, rather than subjects, intellectually interesting as they are, such as the outlines of the Bahá'í World Commonwealth of the future, for which new political structures will be necessary. Before turning to this endeavor, however, let us summarize a few of the relevant Bahá'í principles, which may serve as a rich resource and source of inspiration.

\section{Some Basic Bahá'í Principles}

A central principle of the Bahá'í Faith, "the pivotal principal and fundamental doctrine of the Faith," is the principle of the oneness of the entire human race (Shoghi Effendi, God Passes By 281). Bahá'u’lláh declared that “ $[\mathrm{y}] \mathrm{e}$ are the fruits of one tree, and the leaves of one branch .... So powerful is the light of unity that it can illuminate the whole earth" (Epistle 14). This principle has many dimensions and ramifications. As the Universal House of Justice has observed:

For the principle of the oneness of humankind, as proclaimed by Baháu'lláh, asks not merely for cooperation among people and nations. It calls for a complete reconceptualization of the relationships that sustain society. . . [T] he concentration of material wealth in the hands of a minority of the world's population gives an indication of how fundamentally ill-conceived are relationships among the many sectors of what is now an emerging global community. The principle of the oneness of humankind implies, then, an organic change in the very structure of society. (Message to the Bahá'ís of Iran)

In this light, can we study economics without considering economic justice?

Aside from socialists, Western economists have traditionally separated the question of maximizing output, 
considered the main objective of economics, from the question of the distribution of that output of which, as mentioned above, they prefer to think as a political rather than an economic issue. The concept of the oneness of humankind, on the other hand, emphasizes the need of a social structure that encourages each individual to realize his or her own potential and to be a contributing member of society, which in turn will augment the general happiness and prosperity of society as a whole. As 'Abdu'l-Bahá has stated, "Wealth is most commendable, provided the entire population is wealthy" (Secret 8). The question then becomes: What might the economic system of such a society look like? When we consider this question, can we avoid falling into the trap of framing the debate in terms of socialism versus capitalism or as a struggle between classes? Can we imagine a new type of society, one characterized by reciprocity and mutual help?

In the Bahá'i view, and in keeping with this principle of the oneness of humanity, efforts to improve human welfare must be seen as a collective enterprise, with everyone participating in some fashion, and thus the establishment of a sense of unity must be a first step. As the Universal House of Justice communicated in its 20 October 1983 message to the Bahá'ís of the world, "The key to success is unity in spirit and in action." This theme was also stressed in its annual Ridván message to the Bahá'ís of the world in 2010: "Justice demands universal participation. Thus, while social action may involve the provision of goods and services in some form, its primary concern must be to build capacity within a given population to participate in creating a better world. Social change is not a project that one group of people carries out for the benefit of another."

This theme of capacity building ${ }^{7}$ is also developed at length in the document "Social Action," prepared at the request of the Universal House of Justice in 2012, in which they state: "What appears to be called for ... is the involvement of a growing number of people in a collective process of learning .... Such a process would allow its participants to engage in the generation, application, and diffusion of knowledge, a most potent and indispensable force in the advancement

7 An example of the importance of capacity building is 'Abdu'l-Bahá's encouragement early in the twentieth century of the Bahá'is in North America to build a house of worship, not primarily because such a building was needed at that time (it took many years to construct), but because it was a project around which, He insisted, the whole community needed to unite, learning to work together toward a common objective. The committee charged with overseeing the project was called the Bahá' Temple Unity. The spirit in which the project was conducted and the motives of the individuals involved were as important as the outward form of the project, and the main purpose was capacity building in the community. 
of civilization" (OSED 6). Furthermore, in the 2010 message of the Universal House of Justice quoted above, they state: "Access to knowledge is the right of every human being, and participation in its generation, application and diffusion a responsibility that all must shoulder in the great enterprise of building a prosperous world civilization-each individual according to his or her talents and abilities."

So what, then, is the role of experts and intellectuals in the Bahá'í view? Bahá'u'lláh writes that those who acquire knowledge should be respected (Gleanings 128; Tablets 96-97), but the Bahá'í teachings see the generation and acquisition of knowledge, like other human activities, as something in which everyone should take part, not as the exclusive domain of experts or a particular social class. Baháu'lláh further states: "Knowledge is one of the wondrous gifts of God. It is incumbent upon everyone to acquire it" (Tablets 39). And again: "Knowledge is as wings to man's life, and a ladder for his ascent. Its acquisition is incumbent upon everyone" (Tablets 51). Universal education open to all is a central principle of the Faith, applied since the earliest days of the Faith in Iran and in the present day in many areas of the world through the founding of local schools if none are provided by the state. The Bahá'í vision, then, is one of individuals acquiring whatever knowledge they can, given their abilities and access to education, as long as that knowledge "can profit the peoples of the earth" and does not "begin with words and end with words" (Tablets 52).

Intellectual accomplishment, however, should not lead to a sense of entitlement or superiority (Arbab 17). Economists, like other intellectuals, tend to see themselves as playing a central role in society. In the case of economics this may be true, because economies are defined by rules, and those rules, or government policies, are often based on the theories or influence of economists. But just as one wants a highly trained surgeon working in a well-equipped hospital to perform open-heart surgery, and it is also desirable for the general public to be well-informed about health, nutrition, and disease and to have ready access to information in these fields, so well-trained economists are needed to address complex problems of public policy and the functioning of financial institutions, while the general public should understand the principles of economic life and should be encouraged to take initiative if they are so inspired. Knowledge should be available to all, not confined to a privileged few. The challenge, of course, is how to get different groups to communicate effectively with each other and to benefit from each other's perspectives (Ashraf).

It is notable in this context that the 1 March 2017 message of the Universal House of Justice calls on all Bahá'ís, as individuals and in their communities, to consider the problems of inequity and injustice around them and do what they can to address those problems "using the opportunities their 
circumstances offer them" (Message to the Bahá'ís of the World). There is no mention of waiting for an expert to tell them what to do. But there is also no reason why they shouldn't consult with an expert if it would be helpful. As the Office of Social and Economic Development (OSED) at the Bahá'í World Center has observed, "Social and economic development requires the flow of resources, both material and intellectual" (11).

As an aide in understanding the dynamics of social progress, the Universal House of Justice has also introduced the concept of three protagonists in development: the individual, the community, and institutions (Message to the Bahá'ís of the World dated 26 November 1999 1). Each has an essential role to play. As explained in the OSED document on "Social Action" mentioned above, "the increase of capacity in each of these three protagonists does not occur in isolation; the development of any one is inextricably linked to the progress of the other two" (8). The House of Justice has emphasized, in particular, that those who have previously been excluded must now be included and should become empowered to contribute to this process:

Many who have long suffered are finding their voice and becoming protagonists of their own development, resourceful and resilient. From villages, neighbourhoods, towns and cities are arising institutions, communities, and individuals dedicated to labouring together for the emergence of a united and prospering world that might truly deserve to be called the kingdom of God on earth. (Message to all who celebrate the Glory of God dated October 2017)

The message of the Universal House of Justice of 1 March 2017 also highlights the "foundational concept" in Baháu'lláh's Revelation of "the spiritual reality of man," namely "the nobility inherent to every human being” (Message to the Bahá'ís of the World). Like other religions, the Bahá'í Faith views man as having a higher, nobler nature characterized by altruism, integrity, generosity, forgiveness, and many other virtues, a view that emphasizes man's character and role in society. Importantly, in this view human behavior is not, and should not be, something static. On the contrary, it sees human beings as able to learn, progress spiritually, and strive to become better by developing inherent qualities. Even if, for the individual, the ability to develop slows with age, society can progress through education so that each generation is more developed and capable than the previous one, and mankind thereby fosters "an ever-advancing civilization" (Bahá'u'lláh, Gleanings 215).

Thus, a Bahá'í view of the economic dimension of human society contrasts starkly with the view central to most economic thinking-namely, that human motivation is primarily based on 
self-interest and that this condition is static and simply "human nature." It sets forth a concept of the individual as an inherently social being, one thus influenced by social context and collective incentives, but always in a condition of changing and growing, potentially serving as an agent of social change in a reciprocal relationship with society.

This brings us to the importance of trust. The glue that holds society together is trust. No society can long function successfully without trust and altruism. ${ }^{8}$ There is now a growing concern in the world regarding the decline in trust in social institutions. Unfortunately, we nevertheless see untrustworthy people rising to positions of great power and influence in society, notably in the political, financial, and business worlds. Hardly anyone actually expects politicians to speak only the truth these days. Young people might thus quite reasonably assume that being dishonest is the easiest path to success. In contrast, there are many passages in the Bahá'í writings regarding the importance of trustworthiness and truthfulness, such as the following exhortation of 'Abdu'l-Bahá to those in public service positions: "In discharging the functions of the office to which thou hast been appointed, thy conduct and actions should attest to the highest standard of trustworthiness and honesty, to a degree of sincerity that is altogether above suspicion, and

8 This theme is developed in my article "Trust and Trustworthiness." to an integrity that is immune to the promptings of self-interest" (Compilation of Compilations 342).

More generally, Bahá'ís and the followers of the other major faiths believe that personal or spiritual qualities such as honesty, integrity, humility, selflessness, commitment to stable family relationships, a desire to serve others, a dedication to peaceful resolution of conflicts, and a consciousness of spiritual preparation for the next life as opposed to material rewards in this one are of central importance to the successful functioning of human society, including its economic aspects. In the Bahá'í view, the detachment of modern societies from these core spiritual truths is the main reason for the breakdown in social structures and cohesion and to the successive crises being faced by humanity.

An important general principle here is that man is a social creature and society depends on cooperation and reciprocity, not competition. As 'Abdu'l-Bahá explains: "man cannot live singly and alone. He is in need of continuous cooperation and mutual help. For example, a man living alone in the wilderness will eventually starve. He can never, singly and alone, provide himself with all the necessities of existence. Therefore, he is in need of cooperation and reciprocity" (Promulgation 102.2). In the Bahá'í view, the emphasis in much modern economic and social science thinking on competition as the key to prosperity is entirely misplaced (Karlberg). Rather, prosperity comes from 
collaboration and from a sense of reciprocity resulting in equitable sharing. In this view, for example, economic structures should emphasize the mutual interdependence of labor and capital, with the interests of each, as well as the broader social interest, taken into account ('Abdu'l-Bahá, Promulgation 102.33).

In this regard, a key practical approach enjoined by Bahá'u'lláh is the principle of consultation. For Bahá'ís, consultation means sharing one's ideas in a group while being detached from them and listening closely to what others contribute so that the truth can be found and agreement can be reached on the best way forward. Bahá'u'lláh writes: "Take ye counsel together in all matters, inasmuch as consultation is the lamp of guidance which leadeth the way, and is the bestower of understanding” (Tablets 168). 'Abdu'l-Bahá exhorts: "Settle all things, both great and small, by consultation. Without prior consultation, take no important step in your own personal affairs. Concern yourselves with one another. Help along one another's projects and plans" (Research Department). And the Universal House of Justice has written that decision-making can

benefit from a diversity of perspectives through a consultative process which, understood as the collective investigation of reality, promotes detachment from personal views, gives due importance to valid empirical information, does not raise mere opinion to the status of fact or define truth as the compromise between opposing interest groups. (Message to the Bahá'ís of Iran)

Beyond simply recognizing that human beings are social creatures, the Bahá'í teachings take the Golden Rule a step further and emphasize service to others as being the path to individual spiritual growth as well as the progress of society. As Bahá'u’lláh writes, “Man's merit lieth in service and virtue and not in the pageantry of wealth and riches” (Tablets 138). 'Abdu'l-Bahá further declares: "And the honor and distinction of the individual consist in this, that he among all the world's multitudes should become a source of social good" (Secret 1).

Part of being a productive member of society is to have an occupation and earn a living, within the means and opportunities available. 'Abdu'l-Bahá writes: "Every person must have an occupation, a trade or a craft, so that he may carry other people's burdens, and not himself be a burden to others" (qtd. in Universal House of Justice, Message to the Baháís of the World dated 1 March 2017). In fact, we read in Baháu'lláh's book of laws that: "It is incumbent upon each one of you to engage in some occupation-such as a craft, a trade or the like. We have exalted your engagement in such work to the rank of worship of the one true God" (Kitáb-i-Aqdas \33). In a note, the Universal House of Justice explains that the implementation of this law is "the mutual responsibility of the 
individual and society" (Kitáb-i-Aqdas note 56). So work is seen not only as a material necessity, but as a spiritual exercise as well, in that it confirms the individual's dignity as a contributing member of society, no matter how lofty or meagre one's particular role or station might be. Baháu'lláh has poetically summarized this principle in The Hidden Words: "The basest of men are they that yield no fruit on earth. ... The best of men are they that earn a livelihood by their calling" (Persian nos. 81-82).

In the Bahá'í teachings, in contrast to the attitudes and practices of many other faiths, money and wealth are not seen as in conflict with a spiritual life but rather as part of a coherent lifethat is, if one's wealth is "acquired by an individual's own efforts" and is "expended for philanthropic purposes" or "upon themselves and upon their kindred for the love of God" ('Abdu'l-Bahá, Secret 8; Baháu'lláh, The Hidden Words, Persian no. 82). As the Universal House of Justice states, "The oneness of mankind, which is at once the operating principle and ultimate goal of His Revelation, implies the achievement of a dynamic coherence between the spiritual and practical requirements of life on earth" (Message to the Bahá'ís of the World dated 20 October 1983 602). ${ }^{9}$ Thus,

9 For an excellent statement on coherence between the spiritual and the material, see http://www.bahai.org/beliefs/godhis-creation/ever-advancing-civilization/ coherence-between-spiritual-material. in the Bahá'i view, no material or economic act can be separated from its moral and spiritual implications, and economic systems need to be viewed in the light of spiritual standards and objectives. As the Universal House of Justice affirms: "The teachings of the Faith leave no room for doubt: there is an inherent moral dimension to the generation, distribution, and utilization of wealth and resources" (Message to the Bahá'ís of the World dated 1 March 2017).

One example of this perspective is the unique and interesting law of Huqúqu'lláh ordained by Baháu'lláh in his Most Holy Book (Kitáb-i-Aqdas 9 97). In addition to extoling charity, He decreed that those Bahá'ís whose income exceeds their needs must pay nineteen percent of the excess to the Center of the Faith, in a spirit of "the utmost joy and radiance" to be expended for the betterment of humankind (Huqúqu'lláh no. 5). Baháu'lláh has stated that these payments of Huqúqu'lláh “purify” one’s wealth (Kitáb-i-Aqdas 9 97). Thus, the individual can feel at peace spiritually if he prefers to keep the remaining 81 percent. The law encourages Bahá'ís to think of wealth as a means of promoting social good while helping them be detached from such wealth, and it focuses their attention on what is truly "needful" materially in their lives.

As another example of how practical matters intersect with spiritual principles in the Bahá'i teachings, Bahá'u'lláh has specified that the charging of interest is permitted, in 
contrast to other faiths, but He warns against "illicit gains obtained by usury" and counsels "moderation and fairness," "justice," and "tender mercy and compassion" (Tablets 133-34). Similarly, in many passages He extolls forbearance, presumably using the word in its broader sense of showing patience and resignation and not always insisting on one's rights but perhaps also in its narrower meaning of being lenient regarding the repayment of loans if repayment would entail hardship. He has also prohibited gambling but did not elaborate (Kitáb-i-Aqdas $\mathbf{q}$ 155). Therefore, it is for the Universal House of Justice to determine in the future whether this prohibition might include speculation in financial markets (Kitáb-i-Aqdas note 169).

Although there are some specific teachings of the Bahá'í Faith, such as those mentioned above, that could be considered economic in nature, there is no economic system per se envisaged in the writings of the Faith. In a letter written on his behalf, Shoghi Effendi states:

There are practically no technical teachings on economics in the Cause, such as banking, the price system, and others. The Cause is not an economic system, nor can its Founders be considered as having been technical economists. The contribution of the Faith to this subject is essentially indirect, as it consists in the application of spiritual principles to our present-day economic system. Bahá'u’lláh has given us a few basic principles which should guide future Bahá'í economists in establishing such institutions which will adjust the economic relationships of the world. (Hornby 551)

Economists inspired by the Bahá'í teachings may study such issues as taxation, trade, the financial system, and public policy in general, about which some thoughts are presented below. However, they might be well-advised to keep in mind that there are already many worthwhile ideas for improving economic systems, but vested interests and the failings of political systems stand in the way of implementing them. Although it might be useful to prepare the ground intellectually for reforms, most have little prospect of being implemented any time soon. In this context, the emphasis placed at this time by the Universal House of Justice on individual and community action is most interesting. As they explain in their message to the Bahá'ís of the world dated 1 March 2017, "The aim is to learn about how to participate in the material affairs of society in a way that is consistent with the divine precepts and how, in practical terms, collective prosperity can be advanced through justice and generosity, collaboration and mutual assistance."

There is much work to be done to better understand how this process might unfold. 
Promising New Directions

Let us now turn to some specific areas that are currently the subject of intense policy debate because the shortcomings of the present system are becoming apparent, areas where innovations, experimentation, insights, and research, informed by Bahá'í principles, might be particularly fruitful.

\section{New Perspectives on Human NATURE}

As mentioned above, the foundations of modern macroeconomics have been increasingly called into question, leading to more attention being paid to microeconomics, or the study of the behavior of individuals and firms, and in particular to drawing conclusions from observing actual behavior. Important work has been done in many areas, such as game theory and bargaining, limited information, and agency theory, that challenges the restrictive assumptions of the neoclassical models of human behavior. This shift in emphasis has moved what is now called behavioral economics to center stage, with four Nobel Prizes in the past 15 years being awarded to pioneers and contributors to this field. ${ }^{10}$ Nava Ashraf, a young Bahá'í behavioral economist previously at the Harvard Business School and now

10 These Nobel Prize winners include Daniel Kahneman (a psychologist) and Vernon Smith in 2002, Robert Shiller in 2013, and Richard Thaler in 2017. at the London School of Economics, has contributed to this field through high-profile empirical research confirming a theory that people may voluntarily choose to limit their own options - for example, through a bank savings product that would restrict their withdrawals until they reached a given level—contradicting a basic premise of neoclassical economics that people know what they want and that choice is always better. ${ }^{11}$

Ashraf has more recently been doing pioneering work in her study of altruistic behavior, confirming a view of human behavior in line with Bahá'í principles but startlingly different from the one traditionally assumed in the economics profession. She has shown that altruism not only is important, but can be a greater motivation than monetary reward (Ashraf, Bandiera, and Jack). While economists in recent years have extended the idea

11 See in particular "Tying Odysseus to the Mast: Evidence from a Commitment Savings Product in the Philippines.” Behavioral economics is now perhaps most famous for the idea that people can be encouraged to make choices that are better for themselves and/or society by adjusting the way choices are presented to them, e.g., by making the default option in their paycheck involve putting part of it into a savings plan, rather than requiring them to opt for such an option. This idea was popularized in Richard Thaler and Cass Sunstein's 2008 book, Nudge: Improving Decisions About Health, Wealth, and Happiness. 
of human preferences to include various aspects of altruism, fairness, and values, these preferences have been assumed to be fixed in line with the neoclassical model of behavior. Ashraf has now introduced the notion, in a formal model, that altruism can be developed, which, from the perspective of ethics and moral philosophy and of the Bahá'í teachings, is, in fact, of central importance (Ashraf and Bandiera 70-75). Her work is an excellent example of how someone approaching a field of study with a different perspective can see a different reality and cast new light on important issues.

Related to the concept of altruism is the Bahá'i principle mentioned above that the purpose of human life is "service and virtue," and that happiness and fulfillment lie not in material possessions and pursuing self-interest but in service to others and leading a meaningful life. The new field of "happiness economics" addresses questions of this nature, such as whether wealth increases happiness and what other factors might produce happiness and a sense of well-being. In his 2005 book Happiness surveying the subject, Richard Layard emphasizes man's social nature - that happiness comes from social connections such as friendship and marriage - and also observes that "happiness depends on your inner life as much as on your outer circumstances," on "feel[ing] more for others" and on our "inner strength of character" (230). While there has been some effort to make happiness an official objective of government policy alongside GDP and economic growth, and there is even an OECD Better Life Index, the difficulty of defining and measuring happiness has proven an obstacle, and little practical progress has been made. This field appears ripe for further investigation, perhaps drawing on data from the experience of Bahá'í communities.

The elimination of PREJUdice

AND THE RECOGNITION OF GENDER EQUALITY

Prejudices of all kinds that divide society into distinct groups and treat different groups unequally are the antithesis of the Bahá'í principle of the oneness of humankind. So too are barriers to the full participation by women in both economic activity and in social structures the antithesis of the Faith's teaching that women and men are equal in the sight of God. Despite the progress that has been made in recent decades, pernicious prejudices are still rampant in the world and not only perpetrate injustices, but also impede the general progress of humanity. Bahá'ís, with their vision of a society characterized by unity in diversity (Shoghi Effendi, World Order 41-42), should be trailblazers, as individuals and in their communities, in demonstrating how divisions can be overcome and unity firmly established. This is the essence of the community-building projects in which Bahá'ís and their collaborators are engaged and which surely will yield lessons for the path toward 
the economic prosperity and social progress of humankind.

\section{INEQUALITY}

Economic inequality, and in particular the startling increase in affluence of the very rich at the expense of the middle classes in recent years, has moved center stage in political and economic debate in many Western countries. Oxfam announced during the 2017 World Economic Forum that their research showed that eight individuals owned as much wealth as the poorer half of mankind ("Just 8 men"). Although one can question their methodology, the overall picture is of profound concern. French economist Thomas Piketty, after fifteen years of research, published his long academic study Capital in the Twenty-First Century in 2014, and it reached number one on the New York Times best seller list for hardcover nonfiction, reportedly selling over 2.5 million copies and presumably breaking records for the sale of any 700-page academic tome ("Hardcover Nonfiction"; Irvine). ${ }^{12}$ The rise in inequality is often mentioned as one of the causes of the loss of public confidence in political leadership in some countries, and there has been concern that it is leading to greater social instability.

Piketty's proposed solution-typical for an economist-is to impose new taxes on the rich to promote equality.

12 Another influential writer on inequality is Branko Milanovic. See in particular his book Global Inequality.
Of course, this seems highly unlikely to happen any time soon. There is also the issue of whether the resources thus raised would be effectively used to alleviate poverty. Redistribution schemes and foreign aid have a poor record of actually promoting equality or development. Many social programs in wealthy countries, although well-intentioned, have been found to perpetuate poverty or to have other negative social effects, and foreign aid programs have been widely criticized as both ill-conceived and supportive of corruption in recipient countries.

With regard to the question of how best to provide support for the poor and needy, an option that is being increasingly discussed is the idea of a universal basic or minimum level of financial support for all citizens. Because of the difficulty of targeting income maintenance schemes only to those truly in need, and without undermining incentives to seek gainful employment, the universal basic income would simply be given to all citizens. It was put to a public vote in Switzerland in 2016 (but failed by a large margin), is being pilot-tested on a limited scale in a number of places such as Finland and Ontario, Canada, and is being promoted elsewhere, including by politicians. However, such schemes do not currently appear affordable even in most of the richest countries, as compared with targeted assistance, although the experiments with this approach are worth following (OECD, "Basic Income" 4, 6). ${ }^{13}$

13 For a detailed treatment of this 
All the above approaches to inequality are what is often called "top down" rather than "bottom up," i.e., directed from a central authority rather than springing from the grass roots. To succeed, approaches to inequality may need to give much greater weight to building a spirit of community at the local level, like the small, intimate "study circles" in which Bahá'ís of different levels of experience read the Bahá'í writings together and share their understandings as equals, in sharp contrast to the format of sermons, lectures, or the use of media typical in other religions and institutions of learning. It is noteworthy that an anti-poverty scheme incorporating some of these community-based elements, with local communities identifying those in need and targeting appropriate assistance to them, is being implemented successfully on a large scale in China (“China's New Approach”). Indeed, it has been my observation that in many cultures where there is widespread poverty, anyone doing better than the rest is expected to give support to relatives and friends, whether in the form of food at traditional feasts or direct financial support, as an important element of community solidarity and social cohesion. ${ }^{14}$

subject, see Van Parijs, Philippe and Yannick Vanderborght, Basic Income: A Radical Proposal for a Free Society and a Sane Economy. Harvard UP, 2017.

14 A Bahá'í PhD student at Cornell, Vesall Nourani, is researching this phenomenon.
In the same vein, the 1 March 2017 message of the Universal House of Justice puts the issue in an entirely different light as compared with the normal view of economists, framing it as a moral, and thus personal, imperative and not just a political or economic question to be addressed by social institutions or public policy. ${ }^{15}$ Individuals and small communities motivated by a moral standard taught by their religion can improve their behavior even before the political structure or economic incentives to do so are changed. As urged by the Universal House of Justice, Bahá'ís can attempt to identify local causes of inequality and address them with the means at their disposal. In a village setting, such causes might include an inequitable irrigation scheme, health issues such as malaria or the need for a clinic or clean water, lack of access to or the quality of education, local social divisions such as caste or rivalries between families, or the corruption of local officials. In any setting, Bahá'ís can just simply show more personal compassion and care for those in need, following the lifelong example of 'Abdu'l-Bahá.

A skeptic might say that relying on people to feel more compassion for others is just wishful Pollyanna thinking. For example, in his recent book Creating Freedom (2016), Raoul Martinez presents a fairly standard critique of capitalism and the inequalities and

15 See, for example, the passage quoted above that "there is an inherent moral dimension" to inequality. 
waste it produces. His main prescription, at the end, is that people should be made to realize, when they spend on non-necessities, that they are actually wasting resources that could be used to save the lives of people in desperate need. One criticism of the book is that his exhortation is unlikely to have any practical effect. Having posed a problem, he hasn't offered a realistic solution. But what he proposes bears a striking resemblance to the Bahá'í law of Huqúqu'lláh mentioned above - the "profoundly private act of conscience that promotes the common good"-which Bahá'ís are obeying with enthusiasm and devotion (Universal House of Justice, Riḍván 1991 Message).

\section{EMPloyment AND TRAdE}

The inability to provide adequate employment to those willing to work is a major failing of modern capitalism and an issue underlying much of the anger currently being expressed in politics. Unemployment, along with the corollaries of wage levels and job security, is a critical issue in the world, especially as it tends to be concentrated in areas of economic decline and among disadvantaged populations and rises abruptly when there are economic or financial crises. In the euro area, for example, overall unemployment reached 12 percent in 2013 and was still 10 percent in 2016, with much higher rates in some countries (Greece at 24 percent and Spain at 20 percent) and among certain segments of the population, such as young people ("Total Unemployment Rate"). In the United States, at the time of this writing, although overall unemployment is low, wages are stagnant, many discouraged workers have stopped seeking employment but are not counted as unemployed, and there are serious regional problems.

Obviously, prolonged unemployment can do permanent damage to one's self-esteem and productivity and make reentry into the workforce increasingly difficult. Those of us whose grandparents lived through the Great Depression of the 1930s heard many stories of people whose lives were crushed through a loss of their sense of self-worth when they became unemployed. In light of the emphasis placed by Baháu'lláh on the importance and value of each individual making his or her contribution to society, Bahá'ís would give high priority to finding solutions to this issue.

Americans, especially, like to refer to their "free enterprise system," but one never hears about a "free worker system." The current economic and political system of "free market" countries encourages and supports business, which in turn is expected to provide jobs, but only in that order, and with the jobs being a residual and an indirect result after other policies are implemented. Although in theory a group of unemployed workers could hire a capitalist to employ them, this never happens in practice (although there are other models such 
as cooperatives and worker-owned businesses that have a mixed record but are worthy of study). While in principle anyone in America can start a business, and new, small businesses are a very dynamic portion of the economy, to start a business one needs both know-how and access to capital, which excludes a very large part of the total population.

The solution to unemployment is not protectionism-the raising of barriers to trade to "protect" domestic industries and jobs. Protectionism engenders retaliation by trading partners and can lead to a trade war, damaging all countries involved. It also effectively freezes the status quo, leading to complacency in protected industries and killing the dynamism of an economy. On the other hand, free trade can increase inequality. While there may be significant economic gains from trade, the way those gains are divided is subject to negotiation, and the stronger partner is likely to capture the larger share. Also, while proponents of free trade argue that the gains are big enough to compensate those who lose, it is challenging to find appropriate ways to effect such compensation. Because many of the long-term unemployed are likely to be poor as a result of their joblessness, some of the practical considerations relating to addressing inequality also apply to trade policy. Thus, while protectionism is a crude tool applied, and often misused, in a world of sovereign nation states, a fairer structure for regulating international trade and dealing with its consequences is called for.

Although protectionism is not the answer, ways need to be found to improve the resilience of industries that are subject to competition, whether foreign or domestic, or to find alternative employment for those who find themselves displaced. The concern now is not only with manufacturing jobs, but also white-collar jobs that appear in danger from developments in artificial intelligence and other information processing technologies. However, if we step back from thinking only in terms of the present economic structure, we can see that the world is far from having run out of things that need to be done to improve our lives and our environment. Whether caring better for the elderly and the sick, beautifying our cities and our homes, enjoying more live music and drama, reading more creative writing, reversing the degradation of nature, improving and extending education, or other vistas opening before humanity that we cannot now even imagine, there should be an infinite amount of productive work for humanity.

The problem, then, originates in the economic structure, in the difficulty of finding ways to pay people for new types of work. It has been proposed that government programs be established that would provide work when the private sector fails to adequately fill this need, like the Works Progress Administration (WPA) program in the United States during the depression of the 1930s (Tanden et al.). But a more effective, or perhaps 
complementary, approach could be to harness and encourage capacity at the local level for social compassion and support, as mentioned above, through personal interaction with each individual leading to a knowledge of their needs and abilities, which likely would include questions of education, training, and health care. The lack of such compassion can often be traced to prejudices of all kinds, including class, race, and gender; to biases in the education system and in hiring practices; and to a legal and economic system that favors and extols the rich and powerful. Perhaps a greater sense of compassion in communities and a breaking down of the barriers created by prejudice will motivate people at the local level, on their own initiative, to find ways to employ the needy. In this way, the needy could contribute something valuable to the community, as opposed to simply receiving charity, and community solidarity would be enhanced.

\section{The Organization of Business Entities}

For businesses attempting to behave ethically, it is difficult to know how to balance social and moral objectives with the profit motive. At a personal level, an individual can try to choose a profession that maximizes social welfare and minimizes conflict with his or her values. But in societies that are riddled with corruption and perverse incentives, it can be very hard to avoid difficult moral choices. In the many countries with weak institutions, government regulations and corruption go hand in hand, and dealing with officials is the greatest challenge an entrepreneur faces. It can be very hard for a small business to survive when competitors who pay bribes or use inside connections enjoy overwhelming advantages. Principled entrepreneurs in such an environment may simply have to give up that line of work and move to something else that may be less remunerative but can help to better align their working life and their values.

When someone is starting a new business or is working in a very small business, it is important to think clearly about objectives, priorities, and incentives. Fortunately, the current legal structure in most countries allows for many types of business entities, including corporations of different sizes, family-owned businesses (the predominant business form in many countries), cooperatives, and sole proprietorships, with a lot of flexibility in internal organization. And there is already a great deal of experimentation specifically aiming to address the needs of all stakeholders, including workers, customers, and the broader society, as well as managers and investors, in the field called social entrepreneurship, a field in which Professor Ashraf is active. ${ }^{16}$ But these experiments are still

16 One of her roles at the London School of Economics is serving as research director of the Marshall Institute for Philanthropy and Social Entrepreneurship. 
limited, with social and environmental impact objectives being mostly a matter of public relations and spin rather than true aims of corporate policy.

The behavior of large and financially powerful enterprises is another central issue in many countries. The culture that primarily values profit and outsmarting competitors can lead organizations into behavior that is extremely damaging to society and even illegal. Witness the recent scandals over emissions produced by Volkswagen automobiles. The general culture is likewise greatly affected by the resultant emphasis on overconsumption, outward appearances, and a superficial, materialistic view of life. Individual workers or managers in such enterprises have to deal with an internal culture as well as an external environment that might not accord with their values. Even the most well-meaning people are affected by the culture and incentive structure in which they find themselves and can face difficult moral challenges.

So the question is, how do we change this type of business behavior? A Bahá'í-inspired organization called ebbf (ethical business building the future) has been serving for twenty-seven years as a forum and organizer of conferences for businesspeople and anyone interested in ethical business practices, helping to meet a need for the exchange of ideas, best practices, and moral support. ${ }^{17}$ It seems to

17 For more information, visit their website at http://ebbf.org/. accord with the vision of the Universal House of Justice in its 1 March 2017 message regarding innovation at the working level. There is certainly plenty of scope for experimentation in the way businesses are run, and there is also a clear role for academic researchers to study different models using rigorous methods as part of the learning process.

\section{The Organization of Public \\ Service and the Size of the Public \\ SECTOR}

Governments are a very large part of modern economies. There is a never-ending political battle over the proper size and scope of government and the taxes that support it. The private sector is subject to many shortcomings, prompting the need for regulation, but the public sector suffers from its own afflictions, primarily those of perverse incentives. So one aspect of the policy challenge is how to make public service entities work better.

In a bureaucracy, to protect and expand one's domain it is usually necessary to spend all of one's budgeted resources and find justifications for an increase in the next budget cycle. If one's budget is under threat, a common tactic is to cut or threaten to cut the most visible and important activity. A true effort to eliminate waste and improve efficiency is rarely rewarded. Innovation is almost absent. Armies, schools, police and fire departments, and so forth operate now more or less 
as they did a century ago. How, then, do we create incentives within large bureaucracies to improve performance while minimizing costs? How do we introduce a more consultative and service-oriented culture? How can organizations, and indeed whole societies, bring about moral and altruistic behavior?

In Western countries it is widely believed that the rule of law, with appropriate institutions (police and courts), are a chief source of motivation for citizens to behave well. It is also recognized that a "capitalist" system based on the incentives of profit and personal enrichment produces many "negative externalities" (negative effects on others and society), and that such tendencies need to be curbed through laws and regulations imposed by the government. In reality, however, laws and regulations and the institutions that enforce them can only affect marginal behavior, i.e., the most extreme cases of deviation, while the behavior of the general population is guided more by unwritten cultural norms. Furthermore, people are clever in finding ways around laws and regulations. A modern economy is complex and changing, and the challenges of responding to problems as they arise through new laws and regulations means they proliferate, eventually strangling economic activity and innovation. The US domestic tax code (Title 26), for example, contains 100 chapters and almost 10,000 sections, each having up to four layers of subsections. It is so poorly written and dense, with so many cross references, sometimes circular, that it can be difficult to discern the intent even after careful study. Although it is an attempt to produce a just system based on clear rules, it ends up becoming an enormously expensive, time-consuming disaster. And that is just the US federal government. There are also state and local codes. For example, the California code covering general education (public schools) has more than 8,800 articles, some of which are quite lengthy and contain numerous subsections. The situation is so extreme that is has become absurd.

Perhaps the solution to this central dilemma of economic policy-how to achieve economic justice through fair and enforceable rules-is to look at the problem from a different perspective. As mentioned above, instead of assuming that individuals are mainly motivated by self-interest and greed that needs to be constrained, greater reliance needs to be placed on the moral development of the individual and the moral standards of society. It is here that Baháís and those who sympathize with Bahá'í principles must increasingly demonstrate the power of individual commitment to moral behavior, while eschewing the religiosity, closed-mindedness, and sense of superiority that many people find so objectionable in the attitudes of organized religions. In organizations as well as in society as a whole, this approach may entail having fewer meaningless rules and regulations and relying more on a common sense of what is decent and 
moral behavior. How such an approach can be implemented in practice, however, is probably a question of learning from experimentation, much the same process as innovation in businesses.

\section{The Financial System}

The financial crisis of 2007-08 demonstrated that problems with the financial system can be extremely costly and damaging. The average employment rate of developed countries only recovered to the pre-crisis level nine years later (OECD, OECD Employment 22), prompting political backlash and efforts to make the financial system more stable through increased regulation and higher capital requirements. However, heaping more regulations on an already highly regulated sector brings costs with it, and highly paid, highly incentivized bankers and their lawyers continue to find ways to avoid or exploit regulations and maximize their profits. In this regard, it is instructive to look at the outsized proportion of total corporate profits in America earned by financial sector companies. In the 1970 s and 1980 s they earned on average 17 percent of all domestic corporate profits. The figure jumped by 10 percentage points in 2001 and reached over 37 percent in 2002. Even after the financial crisis of 2007-08 and the scaling back of some of the speculative and exploitative activity in the sector, the industry still captured 27 percent of all corporate profits in 2016 (US Bureau of Economic Analysis). Few could seriously argue that the contribution of the financial sector to the welfare and productivity of the US economy actually warrants over one-quarter of all domestic corporate profits. It is quite clear that the sector is still capturing extraordinary benefits because of its position of power and access to information, often by blatant exploitation and even corruption (Kotlikoff 1-122).

As a result of the crisis, some economists and former bankers have spoken out about the need for a fundamental rethinking of the structure of modern banking and finance, among them former governor of the Bank of England Mervyn King. ${ }^{18}$ Perhaps most interestingly, a proposal known as the Chicago Plan, first made in the 1930s and supported by the famous Yale economist Irving Fisher, has been revived. Rather than allowing banks to create money whenever they make a loan, subject only to general restrictions on their level of capital and reserves, the plan proposes that only the government be allowed to create money and that banks be restricted to managing it. This idea, which comes in different flavors and is now often referred to as "narrow banking," "full-reserve banking," "100\% reserve banking," or "limited purpose banking" has been supported and elaborated recently by a number of respected economists ${ }^{19}$

18 See King's book The End of Alchemy.

19 See, for example, John Kay's article "Should We Have 'Narrow Banking"?" and his book Other People's Money; Laurence Kotlikoff's Jimmy Stewart Is Dead; 
and other writers (Jackson and Dyson) and in an IMF working paper (Benes and Kumhof). One virtue of such a system is that it would eliminate the largest source of instability in the current financial system by reducing or eliminating financial risk-taking by government-backed financial institutions (which leads to "moral hazard" or excessive risk-taking) and forcing investors to accept such risk directly.

The fact that Bahá'u'lláh has permitted the charging of interest does not necessarily imply that the government should assume a major part of the risk in the banking system, as is currently the case. Because the ups and downs in finance generally benefit "insiders" who can make fortunes at the expense of the general public, greater financial stability would also reduce the inequities in the present system and would likely encourage capital to flow into more productive and less speculative investments. This is a topic that could benefit from further study.

\section{Natural Resources and \\ Protecting the Environment}

Protecting the natural environment and enhancing the manmade environment are natural priorities for a community that emphasizes the common good. Environmental pollution, often caused by actions that might benefit one individual or company but negatively affect society, is

and Adair Turner's Between Debt and the Devil. the classic example in economics of negative externalities. The usual prescription is government regulation, although, as noted above, the actual implementation of regulations can be highly problematic, and in this arena there are large and continuing political battles. But pollution, or simply trash or lack of maintenance, can be an important local issue as well, amenable to local solutions. Progress in reversing environmental degradation may also depend in large part on education, increasing the public's awareness of the nature of the problem. In this context, it is noteworthy that Bahá'í junior youth groups in different parts of the world often choose, on their own initiative, a local cleanup, park beautification, or gardening project as a first service project. The benefits can often far exceed the stated goal of the project itself or the education of the youth, as the community sees the interest of the young people in improving their surroundings and begins to question its own indifference and inaction. When a junior youth gardening project in a blighted neighborhood of Baltimore was mowed over by a city worker, the youth involved turned to social media to publicize the incident and soon the local television station was on location filming, resulting in the deputy mayor helping to replant the garden amid more publicity for this public-spirited initiative by the youth (Sobhani). In this process, the youth also develop an important capacity for positive social action. 
Of course, although drawing the attention of youth to environmental problems and encouraging them to take action, however modest, is an important educational step and may have broader impacts, social structures that lead to the despoiling of the environment are often linked to the exploitation of populations, not just of natural resources, and thus are related to the issues of prejudice, class divisions, and inequality discussed above.

\section{Corruption}

Corruption, broadly defined to include privilege, injustice, exploitation, and organized crime, is arguably the most important economic and political problem of our time. In Western countries, public trust in institutions of all kinds regularly hits new lows. For example, in recent Gallup polls only 8 percent of Americans rate congressmen as highly ethical, below 9 percent for car salesmen ("Honesty/Ethics”). And President Barack Obama, in his first State of the Union address, declared: "We face a deficit of trust." Economists can argue about the relative merits of different economic systems such as capitalism and socialism, but the reality, as we can see plainly in the world, is that any system can be more or less corrupted, and the degree to which it is-more than any other variable-explains success measured in terms of the general welfare of the population. Corruption has thus moved to the center stage in much of the political struggle of our time.
When moral consensus in society breaks down, corruption flourishes. Corruption requires access to power. The corrupt are therefore in a position to protect themselves very effectively and can only be constrained when a broad social movement arises in opposition, such as the non-violent movement spearheaded by Gandhi in India and the many color movements that started with Solidarity in Poland.

Thus, although studying techniques for curbing corruption is useful, the broad political will to actually stop corruption will only arise when populations can rally around a moral consensus, a "shared ethic" (UHJ, Message to the Bahá'ís of the World dated 1 March 2017). For Bahá'ís, then, the priority is to work on awakening and developing the moral consciousness of the population, and this effort is most effective when starting with children and youth. Individuals can also lead by example. As the standards in public service decline, the need for people who establish a reputation for competence, integrity, and dedication to service increases, and their example can help raise the expectations of the public regarding the qualities required for such service. As always, actions speak louder than words.

The impact of dishonesty and selfishness on economic prosperity is particularly pernicious, as can be seen in the growing reaction against corruption worldwide. Whether or not corruption is actually getting worse, however, is an interesting question, given that human beings have been 
exploiting their fellow man at least as long as recorded history. It may be that it has merely become more visible and harder to hide as technology has greatly enhanced the general public's access to information and increased the ease of and incentives for leaks of confidential information. The reaction to corruption may also reflect a declining public tolerance for such behavior and a stricter enforcement of laws against criminal behavior, money laundering, theft, embezzlement, blackmail, illegal resource exploitation, etc., with the resultant heightened publicity of such wrongdoing, giving an appearance of an increase in the underlying activity. In any case, it is encouraging that the public is becoming more aware and less tolerant of corruption, raising hope that this central problem of modern governance will be increasingly addressed.

\section{Integrity in Science and Public Discourse}

Corruption in the broad sense is also eroding the foundations of public discourse and scientific endeavor. Scientific method involves the publication of experimental results so that they can either be confirmed or rejected by the scientific community. Unfortunately, the number of scientific papers published in the leading journals that cannot ultimately be confirmed by other scientists is creating "growing alarm” ("Challenges"; Baker; Nosek et al.). Presumably, this trend partly reflects the pressure on scientists to publish, but it also likely reflects financial and other incentives to produce the results desired by interested parties, as well as the general decline in moral standards in society. Such an erosion of ethics strikes at the heart of a process of discovery of the truth that has been central to the leap in human welfare in modern history.

An extreme, but instructive, example of the forces at work is the case of David Kelly, a Bahá'í scientist and authority on biological warfare who was asked by the British government to investigate the existence of weapons of mass destruction in Iraq in 2003, when this was a high-profile political issue. He reported honestly that he found none, but his findings were in direct contradiction to a public statement on the subject by the British prime minister and were ignored, although later proven correct ("Dr David Kelly"; Gilligan). Other examples of the overwhelming influence of vested interests, from industry and the field of nutrition and public health, are recounted by Dr. T. Colin Campbell (in part 4 of The China Study) and Gary Taubes (in The Case Against Sugar).

More recently, concern is rising that public discourse is being corrupted by political propaganda, including "fake news" and "alternative facts," and undermined by a tendency in the Internet age for people to listen only to opinions and news that they want to hear.

In economics, there has already been a welcome move to publish the datasets underlying studies and publications, 
leading to useful debates-for example, debates about Piketty's methodology and whether his conclusions are justified. However, we should not underestimate the difficulties that an economist may face if he or she challenges the accepted wisdom of the field or of public policy or threatens vested interests. Those approaching economics from a Bahá'í perspective will need to rise to the challenge of trying to harmonize their work with high principles of integrity, honesty, and an unbiased perspective.

\section{Conclusion}

The principle of the unity of mankind has far-reaching implications. It encompasses the need to break down the barriers between groups of people, including between intellectuals and the general public, and to involve everyone in the process of knowledge creation and social and economic development, empowering people to become the protagonists in their own development within a social context characterized by reciprocity and mutual support. A view of God's creation as one whole also implies the breaking down of barriers between fields of study. It implies viewing human society as a single system, one which we choose to view and study from different perspectives, while becoming increasingly aware of the interrelationships within the whole. It presents enormous intellectual challenges but also great opportunities.

It can be difficult to conceive of a society based on very different principles than those favored at present, even assuming that social structures can be transformed over time by the positive influence of a new religious revelation and by the destructive breakdown in the present order that, in the words of the Shoghi Effendi, "welds the limbs of humanity into one single organism, indivisible, purified, God-conscious and divinely directed" (Messages 45). It is also challenging to visualize how noble spiritual principles can be applied through the actions of individuals and communities in the context of today's fractured, disoriented societies. But the Universal House of Justice is now calling upon Bahá'ís to increasingly face this challenge of making their actions coherent with their principles. This article has been a reflection on what form such efforts might take and on the possible relationship between the academic field of economics and the actions of individuals and communities within the circumstances in which they find themselves.

When examining some of the areas of current debate and concern about the functioning of the economic systems of the world, it becomes apparent that the Bahá'í teachings have a great deal to contribute on these subjects, opening up the potential for useful contributions both by professional economists inspired by the Bahá'í teachings and by individuals and communities generating knowledge about how spiritual principles can be applied to economic life. Indeed, one could conclude that from the point of view of the Bahá'í teachings, much of 
the present field of economics needs to be rethought. The process of generating knowledge at the individual and local level holds out the promise that as Bahá'ís endeavor to act in accordance with their principles in diverse life situations, with integrity and a desire to be of service to others, they may well find ways not only to change their own lives, but to influence those around them and gradually transform the structures of society in general.

\section{Works Cited}

'Abdu'l-Bahá. Paris Talks: Addresses Given by 'Abdu'l-Bahá in 1911. Bahá’í Publishing, 2006.

- The Promulgation of Universal Peace: Talks Delivered by Abdu'lBahá during His Visit to the United States and Canada in 1912. $2^{\text {nd }}$ ed., US Bahá'í Publishing Trust, 1982.

- The Secret of Divine Civilization. US Bahá'i Publishing Trust, 1990.

Arbab, Farzam. "The Intellectual Life of the Bahá'í Community." Journal of Bahâ'í Studies, vol. 26, no. 4, 2016, pp. 9-21.

Ashraf, Nava. "Co-Generating Knowledge through Action-Research: Field Experiments in Behavioral Economics." Vimeo, uploaded by the Association for Bahá'í Studies, 2014, http://vimeo.com/85871638. Accessed 17 October 2017.

Ashraf, Nava, Colin F. Camerer, and George Loewenstein. "Adam Smith, Behavioral Economist.” Journal of Economic Perspectives, vol. 19, no. 3, 2005, pp. 131-45.

Ashraf, Nava, and Oriana Bandiera. "Altruistic Capital." American Economic Review: Papers \& Proceedings 2017, vol. 107, no. 5, 2017, pp. 70-75.

Ashraf, Nava, Oriana Bandiera, and Kelsey Jack. "No Margin, No Mission? A Field Experiment on Incentives for Public Services Delivery." Journal of Public Economics, vol. 120, 2014, pp. 1-17.

Ashraf, Nava, Dean Karlan, and Wesley Yin. "Tying Odysseus to the Mast: Evidence from a Commitment Savings Product in the Philippines." Quarterly Journal of Economics, vol. 121, no. 2, 2006, pp. 635-72.

Bahá'u'lláh. Epistle to the Son of the Wolf. US Bahá'i Publishing Trust, 1962.

- Gleanings from the Writings of Baháu'lláh. Translated by Shoghi Effendi, rev. ed., US Bahá'í Publishing Trust, 1952.

—. The Hidden Words. Translated by Shoghi Effendi, US Bahá'í Publishing Trust, 2003.

—. The Kitáb-i-Aqdas: The Most Holy Book. Bahá'í World Centre, 1992.

—. Tablets of Baháu'lláh Revealed after the Kitáb-i-Aqdas. Edited by the Research Department of the Universal House of Justice, translated by Habib Taherzadeh et al., Bahá'í World Centre, 1978.

Baker, Monya. "1,500 scientists lift the lid on reproducibility." Nature, vol. 533, no. 7604, 25 May 2016. 
Benes, Jaromir, and Michael Kumhof. "The Chicago Plan Revisited." IMF.org, 2012. PDF, http://www.imf.org/external/pubs/ft/wp/2012/wp12202. pdf. Accessed 3 October 2017.

Broadberry, Stephen, and John Joseph Wallis. "Growing, Shrinking, and Long Run Economic Performance: Historical Perspectives on Economic Development.” National Bureau of Economic Research, April 2017. PDF, http:// www.nber.org/papers/w23343.pdf. Accessed 17 October 2017.

Campbell, T. Colin, and Thomas M. Campbell II. The China Study: The Most Comprehensive Study of Nutrition Ever Conducted and the Startling Implications for Diet, Weight Loss, and Long-Term Health. Rev. ed., BenBella Books, 2016.

"Challenges in irreproducible research." Nature, http://www.nature.com/news/ reproducibility-1.17552. Accessed 17 October 2017.

“China's new approach to beating poverty.” The Economist, 29 April 2017, http:// www.economist.com/news/china/21721393-after-decades-successthings-are-getting-harder-chinas-new-approach-beating-poverty. Accessed 17 October 2017.

Dahl, Gregory C. "Economics and the Bahá'i Teachings: An Overview." World Order, vol. 10, no. 1, 1975, pp. 19-40, http://gregdahl.net/wp-content/ docs/wo1975.pdf. Accessed 17 October 2017.

—. "Evolving Toward a Bahá'í Economic System." Journal of Bahá'i Studies, vol. 4, no. 3, 1991, pp. 1-15, http://gregdahl.net/wp-content/docs/ jbs 1991.pdf. Accessed 17 October 2017.

_. "Trust and Trustworthiness." Trust and Trustworthiness, European Bahá'í Business Forum, 2012. Available at <http://gregdahl.net/wp-content/ docs/trust.pdf $>$ Accessed 17 October 2017.

"Dr David Kelly: Controversial Death Examined." BBC.com, 17 December 2011, http://www.bbc.com/news/uk-13716127. Accessed 17 October 2017.

Etzioni, Amitai. The Moral Dimension: Toward a New Economics. Free Press, 1988.

“Total Unemployment Rate.” Eurostat, 8 November 2016, http://ec.europa.eu/ eurostat $/ \mathrm{tgm} /$ table.do? tab $=$ table $\&$ init $=1 \&$ language $=$ en $\&$ pcode $=$ ts dec450\&plugin=1. Accessed 12 May 2017.

Giles, Chris. “The economic forecaster's failing vision.” Financial Times, December 15, 2008 https://www.ft.com/content/50007754-ca35-11dd-93e5000077b07658 (by subscription). Accessed 17 October 2017.

Gilligan, Andrew. "The betrayal of Dr David Kelly, 10 years on." The Telegraph. http://www.telegraph.co.uk/news/politics/10192271/The-betrayal-ofDr-David-Kelly-10-years-on.html. Accessed 17 October 2017.

Hamermesh, Daniel S. "Six Decades of Top Economics Publishing: Who and How?” Journal of Economic Literature 51(1), 162-72, March 2013. $<$ http://pubs.aeaweb.org/doi/pdfplus/10.1257/jel.51.1.162 >. Accessed 14 October 2017. 
"Hardcover Nonfiction Best Sellers." New York Times, 18 May 2014. <https:// www.nytimes.com/books/best-sellers/2014/05/18/hardcover-nonfiction/?_r=0>. Accessed 17 October 2017.

"Honesty/Ethics in Professions." Gallup.com, http://www.gallup.com/poll/1654/ Honesty-Ethics-professions.aspx?g_source=honesty\%2c+ethics\&g_medium=search\&g_campaign=tiles. Accessed 11 May 2017.

Huqúqu'lláh - The Right of God. Edited by the Research Department of the Universal House of Justice, rev. ed., 2009.

Hornby, Helen. Lights of Guidance: A Bahâ'i Reference File. $6^{\text {th }}$ ed., India Bahá'í Publishing Trust, 1999.

Irvine, Jessica. "Increase property taxes to curb rising inequality: Thomas Piketty's warning for down under." Sydney Morning Herald, 10 October 2016, http://www.smh.com.au/business/increase-property-taxes-to-curb-rising-inequality-thomas-pikettys-first-australian-interview-20161008-gry23l.html. Accessed 17 October 2017.

Jackson, Andrew, and Ben Dyson. Modernising Money: Why Our Monetary System Is Broken and How It Can Be Fixed. Positive Money, 2012.

"Just 8 men own same wealth as half the world." Oxfam, 16 January 2017, http:// www.oxfam.org/en/pressroom/pressreleases/2017-01-16/just-8-menown-same-wealth-half-world. Accessed 17 October 2017.

Karlberg, Michael. Beyond the Culture of Contest: From Adversarialism to Mutualism in an Age of Interdependence. George Ronald, 2004.

Kay, John. "Should We Have 'Narrow Banking'?" JohnKay.com, 2 June 2011, http://www.johnkay.com/2011/06/02/should-we-have-narrow-banking. Accessed 17 October 2017.

- Other People's Money; The Real Business of Finance. PublicAffairs, 2015.

King, Mervyn. The End of Alchemy: Money, Banking, and the Future of the Global Economy. Norton, 2017.

Kotlikoff, Laurence J. Jimmy Stewart Is Dead: Ending the World's Ongoing Financial Plague with Limited Purpose Banking. Wiley, 2010.

Lample, Paul. Revelation \& Social Reality: Learning to Translate What Is Written into Reality. Palabra, 2009.

Layard, Richard. Happiness: Lessons from a New Science. Penguin, 2005.

London School of Economics. "What should economists and policymakers learn from the financial crisis?" 25 March 2013, http://www.lse.ac.uk/website-archive/newsAndMedia/videoAndAudio/channels/publicLecturesAndEvents/player.aspx?id=1856. Accessed 17 October 2017.

Marglin, Stephen. The Dismal Science: How Thinking Like an Economist Undermines Community. Harvard UP, 2010.

Milanovic, Branko. Global Inequality: A New Approach for the Age of Globalization. Belknap, 2016. 
Nosek, B. A., et al. "Promoting an open research culture." Science, vol. 348, no. 6242, 26 June 2015, pp. 1422-25.

Obama, Barack. "Remarks by the President in State of the Union Address." The White House: President Barack Obama, 27 January 2010, http://obamawhitehouse.archives.gov/photos-and-video/video/2010-state-union-address\#transcript. Accessed 10 October 2017.

Office of Social and Economic Development (OSED), Bahá'í World Center. "Social Action.” 26 November 2012 http://universalhouseofjustice.bahai.org/involvement-life-society/osed-2012-social-action. Accessed 17 October 2017.

The Organisation for Economic Co-operation and Development (OECD). "Basic Income as a Policy Option: Can It Add Up?” OECD.org, 24 May 2017, http://www.oecd.org/social/soc/Basic-Income-Policy-Option-2017-Presentation.pdf. Accessed 17 October 2017.

—. OECD Employment Outlook 2017. OECD Publishing, 2017, http://dx.doi. org/10.1787/empl_outlook-2017-en. Accessed 17 October 2017.

Ormerod, Paul. The Death of Economics. Wiley, 1997.

Piketty, Thomas. Capital in the Twenty-First Century. Belknap, 2014.

Research Department of the Universal House of Justice. "Consultation: A Compilation.” Rev. ed., Bahá'í World Centre, 1990. PDF, http://www.bahai. org/library/authoritative-texts/compilations/consultation/consultation.pdf?feO88a5d. Accessed 17 October 2017.

Shoghi Effendi. God Passes By. US Bahá’í Publishing Trust, 1957.

- Messages to America. US Bahá'í Publishing Trust, 1947.

—. The World Order of Bahá'u’lláh. US Bahá'í Publishing Trust, 1955.

Sobhani, Felicia. "Who Is Writing the Future? Felicia Sobhani at TEDxYouth@Crocetta.” YouTube, uploaded by TEDx Talks, 15 December 2013, http:/ /www. youtube.com/watch?v=4-Y6Te9Y1ME. Accessed 17 October 2017.

Taleb, Nassim Nicholas. The Black Swan: The Impact of the Highly Improbable. Random House, 2010.

Tanden, Neera, et al. "Toward a Marshall Plan for America: Rebuilding Our Towns, Cities, and the Middle Class." Center for American Progress, 16 May 2017, https://cdn.americanprogress.org/content/uploads/2017/05/17073805/PathForward_MarshallPlan-report1.pdf. Accessed 6 April 2018.

Taubes, Gary. The Case Against Sugar. Knopf, 2016.

The Compilation of Compilations. Vol. 2, Bahá'i Publications Australia, 1991.

The Universal House of Justice. Message to the Bahá'ís of the World on Social and Economic Development, 20 October 1983. Messages from the Universal House of Justice, 1963-86, The Third Epoch of the Formative Age. US Bahá'í Publishing Trust, 1996, pp. 601-04. 
Riḍán 1991 Message to the Bahá'ís of the World. Bahá’i Reference Library, http://www.bahai.org/library/authoritative-texts/the-universalhouse-of-justice/messag 19910421_001/19910421_001.pdf. Accessed 17 October 2017.

- Message to the Bahá'ís of the World, 26 November 1999. Bahá'i Reference Library, http://www.bahai.org/library/authoritative-texts/the-universal-house-of-justice/messages/19991126_001/19991126_001.pdf. Accessed 11 April 2018.

Ridván 2008 Message to the Bahá'ís of the World. Bahâ'i Reference Library, http://www.bahai.org/library/authoritative-texts/the-universalhouse-of-justice/messages/20080421_001/20080421_001.pdf. Accessed 17 October 2017.

- Riḍán 2010 Message to the Bahá'ís of the World. Bahá'í Reference Library, http:// universalhouseofjustice.bahai.org/ridvan-messages/20100421_001. Accessed 17 October 2017.

- Message to the Conference of the Continental Boards of Counsellors, 28 December 2010. Bahá'í Reference Library, http://www.bahai.org/ library/authoritative-texts/the-universal-house-of-justice/messages/20101228_001/20101228_001.pdf. Accessed 6 April 2018.

- Message to the Bahá'ís of Iran on Involvement in the Life of Society, 2 March 2013. The Universal House of Justice, http://universalhouseofjustice.bahai.org/involvement-life-society/20130302_001. Accessed 17 October 2017.

- Message to the Bahá'ís of the World Regarding Economic Life, 1 March 2017. The Universal House of Justice, http://universalhouseofjustice.bahai. org/activities-bahai-community/20170301_001. Accessed 17 October 2017.

- Message to All Who Celebrate the Glory of God, October 2017. Bahá'i ReferenceLibrary, http://www.bahai.org/library/authoritative-texts/theuniversal-house-of-justice/messages/20171001_001/20171001_001. pdf. Accessed 17 October 2017.

Turner, Adair. Between Debt and the Devil: Money, Credit, and Fixing Global Finance. Princeton UP, 2016.

US Bureau of Economic Analysis. "NIPA Table 6.16.” BEA.gov, http://www. bea.gov $/$ iTable $/$ iTable.cfm? reqid $=19 \&$ step $=2 \#$ reqid $=19 \&$ step $=2 \&$ isuri $=1 \& 1921=$ survey\& $1903=239$. Accessed 17 October 2017.

Wolf, Martin. "Conservatism Buries Reagan and Thatcher." Financial Times, 24 May 2017, p. 11.

Yellen, Janet. "Inflation, Uncertainty, and Monetary Policy." FederalReserve.gov, 26 September 2017, http://www.federalreserve.gov/newsevents/speech/ yellen20170926a.htm. Accessed 12 October 2017. 